\title{
Disease Response Group Identifier
}

National Cancer Institute

\section{Source}

National Cancer Institute. Disease Response Group Identifier. NCI Thesaurus. Code C117393.

A character or string that represents a disease response group. 